\title{
Ethnoecology of Banjarese in Managing the Snakehead Fish in Barito River Basin and Tributaries
}

\author{
KRISDIANTO $^{1}$, SLAMAT $^{2}$, PAHMI ANSHARI $^{2},{ }_{\text {AND }}$ OKSI IKA SUSILAWATI ${ }^{1}$ \\ ${ }^{1}$ Mathematics and Natural Sciences Faculty, Lambung Mangkurat University, Banjarbaru, Indonesia. \\ ${ }^{2}$ Fishery and Maritime Faculty, Lambung Mangkurat University, Banjarnaru, Indonesia.
}

\begin{abstract}
Historically, Banjarese is living in lowland around the Barito riverbank, in the southern part of Borneo Island, from about the $12^{\text {th }}$ century. The first part of Banjarese history is a legend, but about the last three hundred years, there are data about Banjarese as a civilization with a kingdom involved in western colonialism history in Indonesia, as the pepper producer in the $17^{\text {th }}$ century. They have settled almost in all Barito river tributaries and its basin and have been a part of the Barito freshwater wetland community, together with other Kalimantan ethnics such as Dayak hinterland or Malay in the coastal. This research aims to elucidate how far Banjarese is involved in managing wetlands, especially in managing snakehead's population, enjoying its benefit and sustainability. We observe the fishers' activity on the field and village along Barito River and its basin and tributaries, visit their villages and interview them, and collect data from forum group discussion. About 60 participative respondents involve in our research. They were interviewed about how to cat the fish, to evaluate ditches, or little ponds positioned lower than the land surface for placed sustainable fishes in a long dry season. The result shows that Banjarese are traditionally managing the population of snakehead as a symbol of prosperity and conserve them for sustainability.
\end{abstract}

Keywords: Ethnoecology, Snakehead, Conservation.

\section{INTRODUCTION}

The Snakeheads are widely exploited as food and ornamental fishes, and so their conservation and management is a priority, where their populations are declining (Benziger et al, 2011). The population of this fish decreased, to be compared to the market need. Therefore, Snakehead's price is higher than other local fresh -fishes, such as carps, gurami, or catfishes. Therefore, this fish is known as the trigger of local economic inflation due to its rarity. Local cannot depend on the natural population. Therefore, there must effort to support artificial breeding.

Correspondence: Krisdianto, Mathematics and Natural Science Faculty, Lambung Mangkurat University, Banjarbaru, Indonesia. Email : krisdianto@ulm.ac.id
Naturally produce about 5944.1 tonnes snakehead fish in 2018, commonly only catching traditionally using fishing-line, gill net, trapped by handmade bamboo square box. Snakehead spreads almost in freshwater Barito river basin is and it able to live in brackish water as said by Nakkrasae, Wisetdee, Charoenphandhu (2015). This fish has been a very long time to become a favourite meal of Banjarese. Nowadays, snakehead has captured and cultured for many activities, such as recreation, medicine, foods sold as fresh capture, salted dry-fish, or seasoning cookedfish at a food stall to the restaurants. Food was also perceived to serve a healing purpose (Reddy and van Dam, 2020). Then Snakehead also captures for promoting healthy food practices and albumin therapy. 
There has a bulk of experience in research and application in the locals to breed this fish, but not much in ethnoecology and conservation. Therefore, this research aims elucidating the extent to which Banjarese is involved in traditionally using and conserving snakehead for sustainable uses.

\section{METHODOLOGY}

We observe fishers' relationship with snakehead use in several villages along the Barito river basin, this region is a series of beels connected to one another by various channels to form a continuous water body during the rainy season. While, the beel area expands into a vast water body with dense aquatic vegetation as long as the Paminggir, Tampakang, Danau Panggang, Babirik, Danau Bangkau, Bajayau villages, in South Kalimantan, Indonesia remains flooded during the monsoon months, it dries out in the long dry season, leaving only patches of water in the central parts of this zone.

We have notice of their ways and time for catching this fish, and examine how they were treating the fish for food or selling to get income. We also interview the buyers or traders, and the last buyer or trader in the restaurant to know the added values. We consider that the snakehead is not just a food product, but it has a proud and social value for Banjarese, so we examine how these fish cause local monetary inflation. We also learn how locals domesticate and culture this fish, and note how Banjarese skill and feeling in culturing this fish are.

We collect and analyze the qualitative and quantitative data with descriptive statistical analysis. This methodology is summarized and adopted from Djidohokpin et al. (2020).

\section{RESULTS}

According to our respondents, the snakehead is a wetland management subject, and it is forbidden to catch the juveniles using electrofishing. On the other hand, people worry about this fish's predatory, but in Kalimantan, people play an essential role in controlling its population. Because most people like Snakehead, so it is not easy to find this fish in the water body close to the human inhabitant. Even locals make bamboo or wooden fences to protect their culture fish from fish anglers. The respondents also explained, it forbids catching fish using electrofishing. However, there are some crimes regarding the use of electrofishing and catching the juvenile.

Banjarese use to consume even the juveniles traditionally, because they know that the snakehead has benefit chemical substances, namely albumin. However, the locals have to learn how to sustain the snakehead directly from the wetland, as follow were using the weaning method to produce the juvenile from the aquaculture, at a different size, and the juvenile was taken from the nature growing to the farms. The farmers knew that snakehead chemically induce the male and female for artificial mating. The local snakehead produces about $80 \%$ of juveniles that have a slow-growing and will not profit from these activities. So, the fishermen can directly harvest for marketing or feeding for the mature snakeheads. Naturally, this fish mates after in early monsoon, about in March to June every year. After about seven or eight weeks of hatching, they become juveniles. If any predator approaches their juveniles, they will be sucked up into the mouth of their parent for protection. While catching season is in about June - August, one year after mating season.

Locals usually culture snakeheads in the 
floating wooden catches and feed once daily with small non-commercial fish that are plenty in the Barito river basin. The locals have fully experience to feed the fish with food and also know well when the fish is hungry or have already full, from their feeding habit. Snakeheads on the wooden catches are likely saving for the farmers, and they will after at least a year or even three years. On that harvesting day, the farmer will get much money from the cage, it is about 700 to US \$ 1000 from each cage.

Fishers know and have a specific place to temporarily protect the juvenile fish before moving the fish to a particular pond protected by bamboo fences or square net. It usually is the way to protect them from the Otters. Protected land at a particular area will be assumed privately protected, locally named "Liang Haruan". It is generally opposite of free water area name "Batang banyu", and will be respected by other parties as privately protected land, named "Beje", which is set in at the end of the long dry season.

According to traders, the Striped Snakehead (Channa striata) and the Red Snakehead (Channa micropeltes) have marketed fishery commodities that are never left in daily fish markets, whatever the size. Locals use this fish for fishing-recreation in the afternoon after work or on holiday. They go to the wetland as an angler or in groups for a short time, overnight, and others for weeks for adventure, both in monsoon or dry season. The yield is usually just for family dinner.

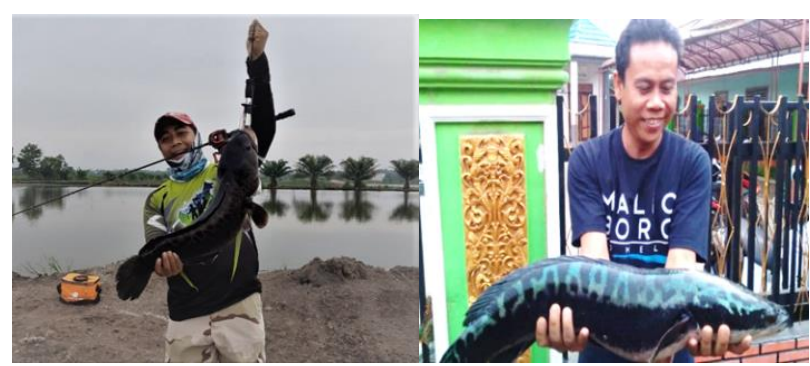

Figure 1. Giant Snakehead capture for recreation and home industrial albumin

Snakehead also captures as a resource for daily consumption, culinary arts for tourism, and the pharmaceutical industry. This fish is usually steamed with red-chili, onion, and garlic, a bit sugar and salt with sour fruit, and it serves with yellow rice, "nasi kuning" is cooked rice with turmeric and a bit coconut milk. Yellow rice is sold in food stalls to the hotel restaurant for breakfast or presented in a religious ceremony. Snakehead also serves for lunch in different spices and seasoning, the fish usually grill with oily spices made from garlic and peanut oil and, named "haruan baubar". Then it is preserved with white rice, sour vegetable contains, lemon, onion, garlic, hot-chili, and boiled green vegetables. In the late afternoon or evening, this fish is served for dinner with coconut-leaves wrapped rice, name "ketupat", made from coconut milk boiled rice. Banjarese can choose to take haruan for daily, weekly, or event monthly family meals. This traditional food is very famous to the national and international tourists who have visited South Kalimantan.

According to buyers, the snakehead directly consumes as cooked meals, and the flesh is fermented with non-oily rice frying as breakfast, named "samu". However, in the city, snakehead sell preserved products, such as dry fish flesh, salty fish, spicy dry flash, mixed-biscuits and crackers, and pharmaceutical-industry products for a source of albumin. Locals have preference size in choosing snakehead, such as for 
household is 200 - 300 grams, for extracted albumin about 500 - 1000 grams, and for aquaculture is more than 1000 grams and especially for Giant Snakehead is preferably more than 3000 grams.
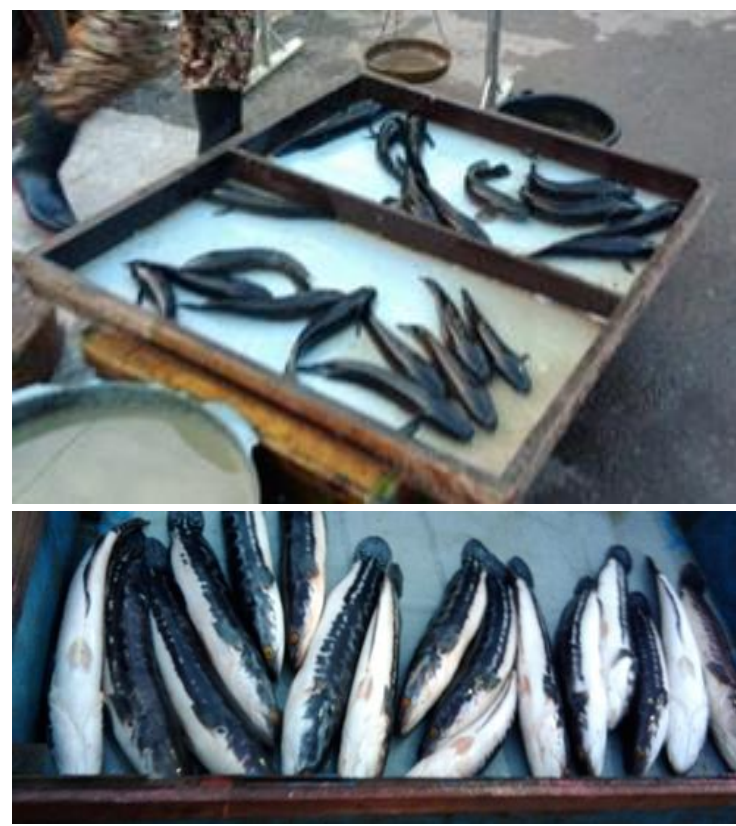

Figure 2. Favourable size of Snakehead for consumption and albumin industry

Officially they reported the electrofishing and poisoning activities to the police and security guard from the local government to promote local fish protection. The local government has provided regulation to manage fishing activities, with punishment for unlawful crime in fisheries protection regulations. In the other hand, the local has traditional skill and knowledge in conserving the local fish, such as beje.

As efforts to conserve the snakehead fish, locals create a pond trap, known locally as beje, a pool constructed adjacent to rivers, inlets, and lakes, and meant to capture fish. The design of this fishing gear is only found in the Kalimantan River Basin. Beje is rectangular and usually measures 5-40 $\mathrm{m}$ in length, 5-20 $\mathrm{m}$ in width, and 1.5-3.0 m deep. In the rainy season (October to April), the beje becomes filled with water that flows in from the adjacent rivers, inlets, and lakes. Simultaneously, the fishes would move into the beje from the stream waters. When dry season (May to September) comes and the water level decrease, then beje is separated from the adjacent waters, and where the fishes from the tributary waters are left in the pool. The fish can, therefore, be harvested from or breed in the beje, which the fishers had covered with branches and twigs to attract the fish to come into, and also to serve as shelters for the fish in the pool. Most beje is connected to a small canal that serves as the conduit for the fish to go into the beje pool. The dimension of the canal is $2.0 \mathrm{~m}$ wide, $1.5 \mathrm{~m}$ deep, and 20-100 m long. The beje pool and canal have soil embankments on one side to keep the water and prevent the fish from escaping into adjacent waters.

Harvesting fish from beje uses a kind of lifting net (known as "hancau") is rectangular in shape and made of polyethylene nylon with 1.5$2.5 \mathrm{~cm}$ mesh size in the stretch. Before harvesting fish from the beje pool, fishers remove the branches and twigs from the pool and put the hancau on the surface of the pool. The edges of the lifting net are fixed to the bottom of the beje. Once the net is fixed, fishers move in mud adjacent to the net, then toward the net position by stirring the mud around the net. It is expected that the fishes will move into the centre of the net. Then the fish will rise to the surface in the centre of the net to breathe, and some of them will jump into the surface as an indicator that the net is full of the fishes. The fishers then get easily caught fist by lifting the net. Some of the swampy fish may not gather in the centre since they are able to live in the mud. In this case, the 
locals can guess the position of fish and try to catch by hand, named "mengacal". In this way, harvesting of fish from the beje pool usually takes 2-6 hours, depending on the fish abundance, and this way is done only once a year, which is during the dry season.

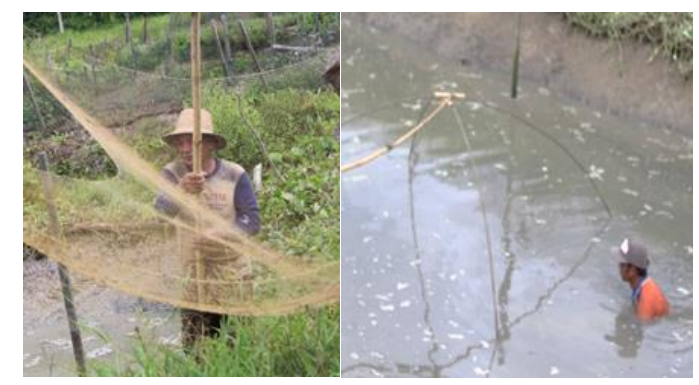

Figure 3. Harvesting swampy fish in Beje.

The local fishers know well about the fish season, and then they used different kinds or sizes of fishing apparatus for catching fish in every different season, so they let other fish grow their population in a different season. It means they are involved in conserving the fish. Traditionally, locals learn very much from generation to generation.

In the wetland's particular position, it has been decided for oil palm plantation in such area reducing the population of snakehead. Therefore, the locals must make more efforts to invites fish to visit their Beje.

\section{DISCUSSION}

Traditionally, the Banjarese catch the fish using local instruments (Irhamsyah and Agustiana, 2018), and has been using snakehead for many purposes. This fish may contribute many health benefits that support activities in the wetland ecosystem against tropical disease (Rajani and Alka, 2015). Albumin from this fish very helpful against the wound or diabetic patients since snakehead has about $7.65 \%$

Journal of Wetlands Environmental Management

Vol 9, No 1 (2021) 85 - 99

http://dx.doi.org/10.20527/jwem.v8i2.264 albumin and $63.78 \%$ total protein content (Romadhonia et al., 2017).

Snakehead increases the fishers' income because it has a higher price than that of other fishes and gives a multiplier effect since this fish can stimulate many kinds of jobs that possibly recruit many people, such as tourism and culinary (Firlianty et al., 2017), pharmaceutical industry (and support the local economy (Grimm-Greenblatt et al, 2015). Snakehead is a fish that is consumed by Banjarese, from breakfast to supper interchangeably. Nowadays, this fish is also involved in the development of local tourism, as well as other ethnic foods which as promoted for ethno-culinary tourism development (Putri et al., 2017). Locals are proud of and enjoy snakeheads, such as fishing adventure, recreation, aquaculture, watergardening, conservation, and industry. The contribution of snakehead constructed advantage from the gastronomy sector is double. It possibly increases its international visibility and attracts foreign direct investments (Tricarico and Geissler, 2017). So, snakehead culinary can expect to stand as a cultural identity and functioning as the local facilitator of Banjarese in national and international relations through tourism, trading, and cultural event exchanges, such as in other countries (Moreno and Malone, 2020).

\section{CONCLUSION}

Snakehead also supports Banjarese's culinary arts, the products such as 'haruan masak habang, abon haruan, gangan asam haruan, garih batanak are cooked fish with local seasoning that are offering from food stall to the prestigious hotel restaurant. In addition, the culture of the snakeheads may mitigate the risk in demand driven of supply chain in sustainable local fish 
conservation.

\section{ACKNOWLEGEMENT}

The authors express their gratitude to the Rector of Lambung Mangkurat University for awarding the Short-Term Research Grant (Contract No 023.17.2.6777518/2020, 16 March 2020), Mathematics and Natural Science Faculty as well as everyone who involved in this study.

\section{REFERENCES}

Benziger A, Philip S, Raghavan R, Anvar APH, Sukumaran M. 2011. Aquacult. Econ. Manag. PLoS ONE 6 6: e21272, doi:10.1371/journal.pone.0021272

Djidohokpin G, Sossoukpè E, Adandé R, Voudounnou JV, Fiogbé, ED, Haour, A. 2020. Ethnoichthyology of Fishing Communities in the Lower Valley of Ouémé in Benin, West Africa. Ethnobiol. Lett. 11:137-151, doi: 10.14237/ebl.11.1.2020.1686

Firlianty, Elita, Pratasik S B. 2017. Fish Meat Processing Inovation of Striped Snakehead (Channa striata), Giant Snakehead (Channa micropeltes) And marble Goby (Oxyeleotris marmorata) on Nutritive Quality of Sate Lilit. IOSR J Environ Sci Toxicol Food Technol (IOSR-JESTFT). 11: 34-37, doi: 10.9790/2402-1110033437

Grimm-Greenblatt J, Pomeroy R, Bravo-Ureta B. Sinh LX, Hien HV Getchis, T. 2015. Economic Analysis of Alternative Snakehead Channa striata Feed. Aquacult Econ Manag, 19: 192-209, doi: 10.1080/13657305.2015.1024345

Irhamsyah, Agustiana. 2018. Kajian bio-teknik penangkapan ikan Gabus (Channa striata) di perairan rawa. In: Prosiding Seminar Nasional Lingkungan Lahan Basah 3.1; 2018 April 24-26, Banjarbaru, Indonesia.
Banjarmasin: LPPM Universitas Lambung Mangkurat, p: 287-292.

Moreno F, Malone T, 2020. The role of collective food identity in local food demand. Agric. Econ. Res. Rev. 1: 21, doi:10.1017/age.2020.9

Nakkrasae L, Wisetdee K, Charoenphandhu N. 2015. Osmoregulatory adaptations of freshwater air-breathing snakehead fish (Channa striata) after exposure to brackish water. J Comp Physiol, 185: 527-537

Putri WK, Hakim L, Inriyani S. 2017. Plants diversity for ethnic food and the potentiality of ethno-culinary tourism development in Kemiren village, Banyuwangi, Indonesia. J. Ind. Tour. Dev. Std., 5: 161-168, doi:10.21776/ub.jitode.2017.005.03.04.

Rajani N, Alka M. 2015. To study the Ethnomedicinal importance of food fish used by localite of Durg. IOSR J Environ Sci Toxicol Food Technol (IOSR-JESTFT), 16: 38-40

Reddy G. van Dam R.M. 2020. The food territory: cultural identity as local facilitator in the gastronomy sector, the case of Lyon. Appetite, 149: 104-633, doi: 10.1016/j.appet.2020.104633

Romadhonia AR, Afriantoa E, Pratama RI, Grandiosa R. 2017 Extraction of Snakehead Fish [Ophiocephalus striatus (Bloch, 1793)] Into Fish Protein Concentrate as Albumin Source using Various Solvent. Aquat. Procedia, 7: 4-11.

Tricarico L, Geissler J-B. 2017. The food territory: cultural identity as local facilitator in the gastronomy sector, the case of Lyon. City Territ Archit, 4:16, doi: 10.1186/s40410-0170072-2. 